\title{
The art of demonstration in anatomy instruction
}

\author{
A arte de demonstrar instruções em anatomia
}

\author{
El arte de la demostración en la enseñanza de anatomia
}

\author{
Saleem Ahmed, Helena Carvalho*
}

\begin{abstract}
As an educator, have you ever wondered why the students in the classroom learn so little despite the innumerable hours you have spent perfecting the lecture? Why, after a brief period of time, do students start losing attention and focus? Many lecturers have experienced this phenomenon, some more than others. To address this issue, in the setting of a fifty minute lecture we've included several demonstrations involving volunteer students and/or economical home created models. Several anatomical concepts, such as the configuration of pleura and thoracic structures and peritoneum and abdominal/pelvic structures, were demonstrated in the classroom using transparent plastic sheets and sleeves, cardboard boxes, plastic bottles and balloons, and often even the students themselves. Such activity was designed to spike the students' curiosity, involvement, interest, and engagement for the length of the fifty minute lecture. These changes were implemented over several lectures during each eight week academic block, and the lectures with such demonstrations were interspersed between other traditional didactic lectures. To our satisfaction, not only did such non-traditional lecturing appear to help the students understand and learn better, but there was better attendance in these non-mandatory lectures, coupled with great enthusiasm, attention, and engagement during the lectures. Our goal in the classroom was to create an environment that helps students to learn effectively. This article presents a teaching approach that engages students by making them part of a classroom activity, which attracts the students' attention and invokes their curiosity with inexpensive home-made anatomy models.
\end{abstract}

Keywords: Active learning; Anatomy Models; Student engagement.

\section{Resumo}

Como educador, você já se perguntou por que os alunos em sala de aula aprendem tão pouco apesar das inúmeras horas que você gastou aperfeiçoando sua aula? Por que depois de um breve período de tempo, os alunos começam a perder a atenção e o foco? Muitos professores têm experimentado esse fenômeno, alguns mais do que outros. Para abordar esta questão, no contexto de uma aula de 50 minutos incluímos várias demonstrações envolvendo estudantes voluntários e/ou modelos anatômicos caseiros. Diversos conceitos anatômicos, como a configuração da pleura, estruturas torácicas e do peritônio e estruturas abdominais/pélvicas, foram ilustrados em sala de aula usando materiais como folhas transparentes de plástico e luvas, caixas de papelão, garrafas de plástico e balões, e muitas vezes até os próprios alunos. Essa atividade foi planejada para atrair a curiosidade dos alunos, aumentando sua participação, interesse e engajamento durante os 50 minutos da aula. Essas mudanças foram implementadas ao longo de várias palestras durante as oito semanas de cada bloco acadêmico na VTCSOM, sendo intercaladas com outras palestras didáticas tradicionais. Para nossa satisfação não apenas esta forma não tradicional ajudou os alunos a entender e aprender melhor, mas também aumentou a frequência destas aulas não mandatórias com grande entusiasmo, maior atenção e envolvimento durante as palestras. Nosso objetivo em sala de aula foi criar um ambiente que ajude os alunos a aprender de forma eficaz. Em resumo, este artigo apresenta uma abordagem de ensino que envolve os alunos, tornando-os parte da atividade em sala de aula, o que atrai a atenção e invoca sua curiosidade com modelos anatômico economicos.

Descritores: Aprendizado ativo; Modelos anatômicos; Engajamento estudantil. 


\section{Resumen}

Como educador, alguna vez se preguntó ¿por qué los estudiantes en el aula aprenden tan poco a pesar de las innumerables horas que usted ha pasado en el perfeccionamiento de la clase? ¿Por qué después de un breve periodo de tiempo, los estudiantes empiezan a perder la atención y la concentración? ¿Por qué algunos estudiantes ya sea se sientan a soñar despiertos o trabajar en sus computadoras portátiles para ponerse al día con sus mensajes de correo electrónico, otros trabajos, o incluso compras en línea? Muchos instructores han experimentado este fenómeno, algunos más que otros. Para abordar esta cuestión en el marco de una clase de cincuenta minutos hemos incluido varias demostraciones involucrando a estudiantes voluntarios y/o modelos económicos creados en casa. Varios conceptos anatómicos, como la configuración de la pleura, estructuras torácicas, peritoneo y estructuras abdominal/pélvica, se mostraron en el aula, usando hojas y fundas de plástico transparente, cajas de cartón, botellas de plástico y globos, y a menudo los propios estudiantes. Dicha actividad se diseñó para aumentar la curiosidad de los estudiantes, la participación, el interés y el compromiso de los mismo durante los cincuenta minutos de aula. Estos cambios se llevaron a cabo en varias clases, durante cada ocho semanas del bloque académico, y las clases con esas demostraciones se intercalaron con otras clases de didáctica tradicional. Para nuestra satisfacción, la clase no tradicionales no solo parece ayudar a los estudiantes a entender y aprender mejor, sino también mejora la asistencia a estas clases no obligatorias, junto con un gran entusiasmo, atención y compromiso durante las mismas. Nuestra objetivo en el aula era crear un ambiente que ayude a los estudiantes a aprender de forma eficaz. Este artículo presenta un método de enseñanza que involucra a los estudiantes, haciéndolos parte de la actividad del aula, la cual llama la atención y la curiosidad de los estudiantes con modelos de anatomía baratos hechos en casa.

Palabras clave: Aprendizaje activo; Modelos; Demostraciones; Compromiso estudiantil.

\section{Introduction}

Whenever the curriculum is delivered utilizing passive didactic lecturing only, it is well-documented that students, after the exams, forget some of the knowledge gained.' Considerable loss of knowledge in physiology has been documented to occur as early as the end of the first year of medical school. ${ }^{2}$ Additionally $26 \%$ of surgeons entering fellowship training were unable to recognize anatomical planes, ${ }^{3}$ knowledge that should have been mastered in the first year of medical school, but was perhaps forgotten as a product of rote memorization. Memorization is essential to some degree, especially in gross anatomy, where a large vocabulary is an intrinsic part of content. The drawback of extensive rote memorization is that retention of the knowledge gained is poor and the facts learned are quickly lost. Learning of gross anatomy, or any learning for that matter, is likely to fail when there is only transference of information from teacher to students with no active involvement of the students.

As stated by DiCarlo, ${ }^{4}$ what and how we teach today will have an impact on students well beyond our lifetime, because each teacher leaves a small part of him/herself in the students they touch. To best prepare our students for medical practice, the focus should be on the learning, not on the teaching. Successful teaching is that through which the learner learns the most, and it is not about a stunning power point presentation furnished by an eloquent professor. ${ }^{5}$

In most medical schools the curriculum requires lectures, and these can be done well when they include active learning, where students have the opportunity to enthusiastically participate, thus making the lecture student centered. A key student behavior that promotes learning is engagement. The question to be discussed is how to best attract a student's attention? Besides reorganizing the lecture and eliminating unnecessary details in order to concentrate on the broad concepts, a teacher should initiate a different activity ever so often to "break the monotony" of lecturing. ${ }^{6}$ Such activity should be based on a lesson plan that will address most or all of the different learning styles, such as visual, auditory, reading/ writing and kinesthetic (VARK). Most students learn effectively if the instructor blends the VARK activities, ${ }^{7}$ where: auditory learners learn by peer instructions, collaborative testing, debate, games and answering questions; kinesthetic and tactile learners learn by role playing and manipulating models; and visual learners by reading and writing.

The amount of knowledge to be acquired by 
the students is too extensive to be taught in the short time assigned to lectures, or during their entire medical school experience for that matter. Due to the explosion of knowledge in medicine, students may easily become overwhelmed with too much material. To overcome those barriers we must be selective about the content we deliver; and we must also be creative and find ways to convey the content in a manner that will "stick", or increase retention. Instructors should focus on the learner by using creativity in the classroom, and several different active learning techniques have already been developed, such as play dough, ${ }^{8}$ dramatization, ${ }^{9}$ and manipulatives. ${ }^{10}$

The objective for this work was to present a teaching approach that engaged students by making them part of a classroom demonstration, which attracted the students' attention and invoked their curiosity by also using inexpensive home-made anatomy models.

\section{Development}

Transitioning into medical school from undergraduate education is not easy for students who now suddenly face a significant increase in the volume of content and are often overwhelmed by the magnitude of it. ${ }^{7}$ To make the anatomy lecture more engaging we decided to focus on delivering the concepts of complex and hard to visualize gross anatomy structures by developing several demonstrations that involved homemade

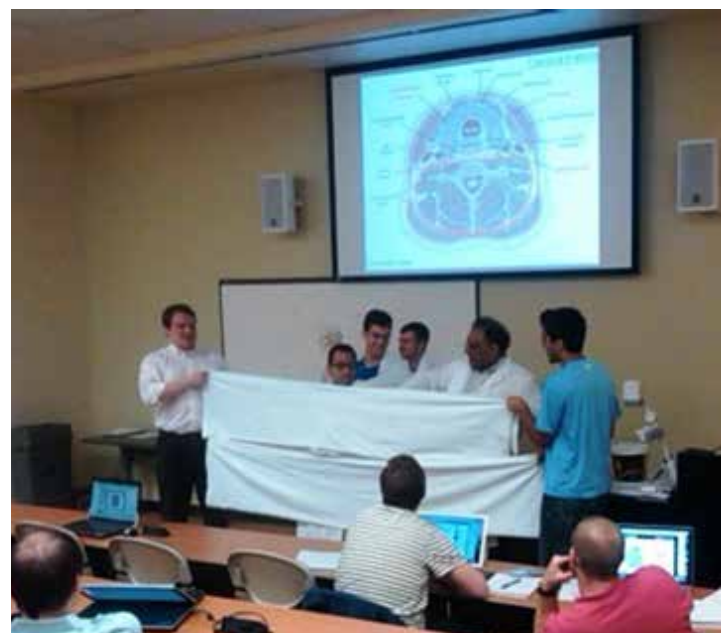

Figure 1a economical large scale models and also practical demonstrations utilizing students themselves playing the role of anatomical structures. Demonstrations were intended to promote better understanding, conceptualization and retention of that knowledge while simultaneously being fun and keeping the students engaged in the class. At times no models were utilized; instead, demonstrations were done using volunteer students, each representing a particular anatomical structure. The students were arranged on the lecture room floor in such a fashion that the true anatomical relationship or position of the structures was revealed with greater clarity. Each student represented a particular anatomical structure and was made to stand, bend or sit depicting the way these anatomical structures are configured in a normal human being (Figures 1a and 1b).

A short description of some of those interactive models used with first year medical students at Virginia Tech Carilion School of Medicine follows.

\section{Student model for elaborating the} anatomical relationship between the rectum, uterus and the bladder

To explain the relationship of the bladder, uterus, vagina and rectum to each other as well as to explain the foldings of the peritoneum over and around these structures, three volunteer students were asked to stand one behind the other. Student 1 , who was most anterior, (i.e in front) represented

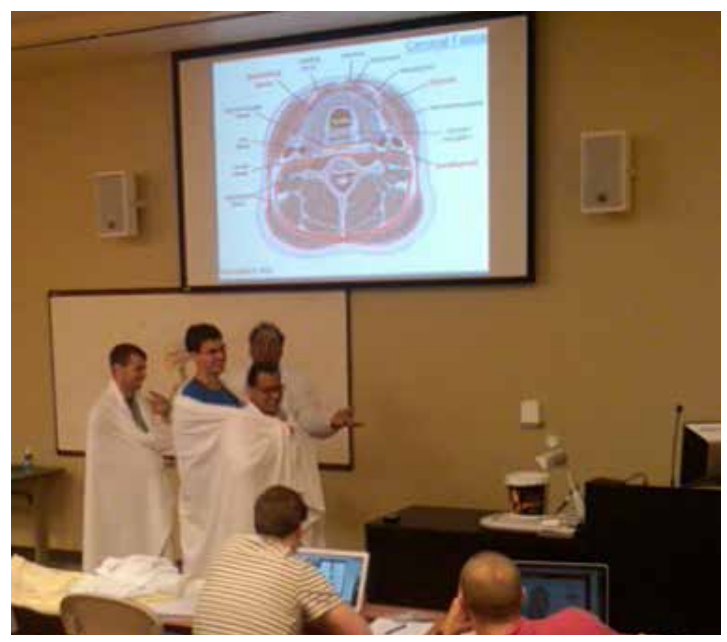

Figure 1b

Figures 1a, 1b. Example of anatomy model demonstration using volunteers' students during lecture. 
the bladder and was asked to sit (the natural shape of a collapsed empty bladder). Student 2 was positioned immediately behind the student 1 and he was designated as the uterus and vagina (from his / her waist up represented the body of the uterus and his / her lower limbs represented the vagina). Student 2 was asked to bend forward at his / her waist so that his / her upper torso rested on the student 1 (representing the bladder). The lower limbs of student 2 represented the vagina and were closely coapted to the back of student 1 depicting the way a normal uterus is configured in a normal female pelvis. Lastly, student 3, usually the tallest, was asked to stand behind the "uterus student" and he / she represented the lower rectum with his / her body.

Then transparent plastic sheets, representing the peritoneum and fascial layers were draped over the students to show the various folds and invaginations these layers make as they move from over the bladder to between the bladder and body of the uterus, to over the uterus to dip down between the "uterus student" and the "rectum student" and finally to cover the front and sides of the "rectum student" as occurs in a normal female pelvis. In a normal person, as the bladder fills with urine, it rises out of the pelvis and pushes the body of the uterus upwards while stripping the peritoneum off the inside of the anterior abdominal wall. These movements and structural changes were physically demonstrated by asking the "bladder student" to rise up from his/her sitting position while pushing the "uterus student" upwards and backwards towards the "rectum student" and simultaneously the plastic sheet covering the bladder (student 1) was raised off the front of the "bladder student" to portray the stripping away of the peritoneum from the inner side of the anterior abdominal wall as the bladder fills and rises up (i.e. superiorly).

\section{Home-made limbs}

To explain the configuration of structures in the limbs, a wooden log representing the arm bone (e.g. humerus) was covered with several celery sticks each representing individual muscles. These sticks were held in place with saran wrap representing the deep fascia. These were then surrounded by a yellow sheet of cloth representing subcutaneous fat which, in turn, was surrounded by a brown sheet of cloth representing the skin.

As the lecture proceeded each layer was described by name, and to keep the students engaged, the students were openly questioned about the contents of each layer. Moving from superficial to the deeper layers each layer of the limb was sequentially removed and great emphasis laid on the most important and clinically relevant anatomical structures. The students were encouraged to refashion similar models in their homes or when studying alone or in groups.

\section{Home-made kidney}

The kidney and its fascial coverings were explained by taking an oval kidney shaped loaf / slice of bread holding it in a way a normal kidney lies in a person. Several different colored bed sheets (yellow for fat, white for peritoneum, and grey for capsule) were taken and wrapped around the loaf to represent the different layers that surround a kidney. Moving from superficial to the deeper layers, each coat / film covering the kidney was described and then the layer / coat was sequentially removed. Once again great emphasis was laid on the clinical relevance.

To describe the renal sinus, the loaf was hollowed out at the midpoint of its vertical length and thin tubes representing the ureter and renal vessels were placed in this hollowed out portion of the loaf of bread to describe the entry, exit and orientation of these structures in relation to the kidney. On the outer surface of the loaf different colored markers were used to show the direction and area supplied by each division and branch of the renal artery. The 'kidney bread model' allowed for fun and invoked curiosity in the class, since at the end of the lecture the instructor chewed off the superior end of the loaf to show how a partial nephrectomy (excision of renal tissue) is performed once the particular branch of the renal artery supplying that area has been ligated.

\section{Home-made peritoneal / pleural sac models}

To better explain the foldings, recesses, reflections and anatomical concepts of the peritoneal sac in the abdomen and the pleural sac in the thorax, inexpensive large transparent plastic envelopes or dry cleaner's sleeves were filled 
with air. The students were distributed at the different sides of this air filled plastic envelope / sleeve. Then organ shaped objects or the fists of volunteering students were pushed into the sac to display / make apparent how the peritoneum and pleural sacs fold over the organs and sheath the vessels supplying these organs. The air filled plastic envelopes / sleeves were wrapped with sheets of different colors (brown for muscle, yellow for fat, white for skin, saran wrap for thin fascia, etc.). Then each layer was described, students were questioned about the contents of each layer and the sheets were sequentially removed till the air filled plastic envelopes / sleeves representing the peritoneal or pleural sacs were reached.

\section{Survey}

At the end of each lecture utilizing anatomy model demonstrations, the students were surveyed about the effectiveness of the demonstration using non-registered audience response system clicking devices. The survey revealed that the use of such models and demonstrations within the lectures helped $75-88 \%$ of the students in conceptualizing and understanding better the gross anatomy of difficult to visualize cadaveric structures while simultaneously keeping them engaged by invoking their curiosity. Additionally, there was higher student attendance in lectures which were non-mandatory and the students went away with a greater degree of satisfaction as reflected by student feedback (e.g. The different modeling methods that Dr. Ahmed uses to teach us difficult spatial concepts are incredibly helpful to our learning"; "Modeling! It helps me understand what is going on! I enjoy the interactiveness, and the use of students to model what is happening.").

\section{Conclusion}

We propose that inexpensive approaches that can be implemented easily in any classroom size be applied within the context of every lecture. The success of such an approach is validated by having volunteer students actively engaged in the activity as part of the demonstration. Several anatomical concepts, such as the configuration of pleura and thoracic structures, peritoneum and abdominal/pelvic structures, were demonstrated in class using transparent plastic sheets and sle- eves, cardboard boxes, plastic bottles, balloons, and often the students themselves.

Many educators persist with traditional, didactic and passive lecturing where the lecturer speaks and the students listen despite established evidence in literature that such a style of lecturing is ineffective and non-conducive to students' learning. "It is understandable that it is difficult to change the way we teach, ${ }^{12}$ but it can be done well and it should be done in incremental changes. In our experience this approach seems to be very efficient, as indicated by the survey using clicker questions, student's evaluation forms at the end of the series of lectures and high attendance for the non-mandatory anatomy lectures.

Active demonstration of difficult concepts in a lecture setting via the models here described greatly helped students to understand the arrangement of important gross anatomy structures, (e.g., the peritoneum and its folds / recesses). Such illustrations were facilitated by active student role playing in the portrayals. The models and demonstrations are easily reproducible and can be applied to any classroom setting. However, careful planning and rehearsal must accompany their implementation, since such demonstrations consume lecture time. In conclusion, such engaging activities promote interest, attention, learning, and fun in class for both students and teachers.

\section{References}

1. Richardson DR. Comparison of naïve and experienced students of elementary physiology on performance in an advanced course. Adv Physiol Edu. 2000;23(1):91-95.

2. D'Eon MF. Knowledge loss of medical students on first year basic science courses at the university of Saskatchewan. BMC Medical Education. 2006;6:5. http://dx.doi.org/10.1186/1472-6920-6-5.

3 Mattar SG, Alseidi AL, Jones DB, Jeyarajah DR, Swanstrom LL, Aye RW et al. General surgery residency inadequately prepares trainees for fellowship: Results of a survey of fellowship program directors. Annals of Surgery. 2013,258(3):440-9. http://dx.doi. org/10.1097/SLA.0b013e3182a191ca

4. DiCarlo SE. Too much content, not enough thinking, and too little FUN! Adv Physiol Educ. 2009,33(4):25764. http://dx.doi.org/10.1152/advan.00075.2009

5. Mazur E. Peer instruction: Getting students to think in class. In: Redish E, Rigden J, editors. The changing 
Role of Physics Departments in Modern Universities: Proceedings of ICUPE Woodbury, New York: American Institute of Physics; 1997. p. 981-8.

6. Richardson D. Don't dump the didactic lecture, fix it. Adv Physiol Educ. 2008,32(1):23-4. http://dx.doi. org/10.1152/advan.00048.2007

7. Lujan HL, DiCarlo SE. First-year medical student prefer multiple learning styles. Adv Physiol Edu. 2006;30(1):13-6.

8. Herur A, Kolagi S, Chinagudi S, Manjula R, Patil S. Active learning by play dough modeling in the medical profession. Adv Physiol Educ. 2011;35(2):241-3. http://dx.doi.org/10.1152/advan.00087.2010

9. Carvalho H. A group dynamic activity for learning the cardiac cycle and action potential. Advan Physiol Edu. 2011:35(3):312-3. http://dx.doi.org/10.1152/advan.00128.2010

10. Krontiris-Litowitz J. Using manipulatives to improve learning in the undergraduate neurophysiology curriculum. Adv Physiol Educ. 2003;27(1-4):109-19.
11. Miller CJ, McNear J, Metz MJ. A comparison of traditional and engaging lecture methods in a large professional-level course. Adv Physiol Educ. 2013;37(4):347-55 http://dx.doi.org/10.1152/advan.00050.2013

12. Silverthorn DU, Thorn PM, Svinicki MD. It's difficult to change the way we teach: lessons from the Integrative Themes in Physiology curriculum module project. Adv Physiol Edu. 2006;30(4):204-14. http:// dx.doi.org/10.1152/advan.00064.2006

\section{Saleem Ahmed}

Bachelor of Medicine, Bachelor of surgery. Fellow of the College of Physicians \& Surgeons of Pakistan.

\section{Helena Carvalho}

Department of Basic Sciences. Virginia Tech Carilion School of Medicine. Roanoke, VA, United States. 